\title{
Changes in physical properties and organic carbon of a Kandiudox fertilized with manure
}

\begin{abstract}
Atributos físicos e carbono orgânico de um Nitossolo Vermelho com aplicação de dejetos
\end{abstract}
\author{
Andréia Patricia Andrade ${ }^{I^{*}}$ Luiz Paulo Rauber ${ }^{I}$ Álvaro Luiz Mafra ${ }^{\mathrm{I}}$ \\ Dilmar Baretta ${ }^{I I}$ Márcio Gonçalves da Rosa ${ }^{I}$ Augusto Friederichs ${ }^{I}$ \\ Maria Sueli Heberle Mafra ${ }^{I}$ Ana Cláudia Casara ${ }^{I}$
}

\section{ABSTRACT}

Successive applications of pig slurry and poultry manure can improve the soil structure, according to the land use conditions and amounts applied. This study evaluated the effect of manure fertilization on the physical properties and organic carbon of a Rhodic Kandiudox. Treatments included land use and management and time of pig slurry and poultry litter application, namely: native forest (NF); yerba mate after 20 years of animal waste application (YM20); pasture after 15 years of application (P15); grassland after 20 years of manuring (PP20); grassland after 3 years of manuring (P3); pasture without application (P0), maize after 20 years of application (M20); and maize after 7 years of application (M7). Soil samples were collected in the 0-5, 5-10 and $10-20 \mathrm{~cm}$ layers, in which density, porosity, aggregate stability, flocculation, penetration resistance, available water, and total clay content, total and particulate organic carbon, and C:N ratio were analyzed. The total organic carbon is sensitive to management and was not related to waste application, except in the 10-20cm layer of ryegrass pasture after three years of manuring. Reponses to waste application and land use and management systems were observed in the variables soil density and penetration resistance.

Key words: animal waste, soil quality, structure.

\section{RESUMO}

Aplicações sucessivas de dejeto líquido de suínos e cama de aviário podem melhorar a estrutura do solo conforme as condições de uso do solo e quantidades adicionadas. Neste estudo, avaliou-se o efeito da aplicação desses fertilizantes sobre os atributos físicos e teores de carbono orgânico de um Nitossolo Vermelho. Os tratamentos contemplam sistemas de uso e manejo do solo e tempo de aplicação de dejeto líquido de suínos e cama de aviário, a saber: mata nativa (MN), erva mate com 20 anos de aplicação de dejetos animais (EM20), pastagem com 15 anos de aplicação (P15), pastagem com 20 anos de aplicação (PP20), pastagem com 3 anos de aplicação (P3), pastagem sem aplicação (P0), milho com 20 anos de aplicação (M20) e milho com 7 anos de aplicação (M7). As amostras de solo foram coletadas nas camadas 0-5, 5-10 e 10-20cm, nas quais foram analisadas: densidade, porosidade, estabilidade de agregados, grau de floculação, resistência à penetração, água disponível, argila total e os teores de carbono orgânico total e particulado e relação $C: N$. O carbono orgânico total é sensivel ao manejo e não teve relação com a adição de dejetos, exceto na camada de 10-20cm na pastagem de azevém 3 anos. A densidade do solo e a resistência à penetração foram as variáveis que tiveram relação com a adição de dejetos e sistemas de uso e manejo do solo.

Palavras-chave: dejetos, qualidade do solo, estrutura.

\section{INTRODUCTION}

Pig and poultry production are economically relevant activities in the State of Santa Catarina. The organic waste is used in agricultural fields as fertilizer, where it can raise the contents of total organic carbon (TOC) and soil nutrients and improve the physical properties (BANDYOPADHYAY et al., 2010 ).

The effects of animal manures on soil physical properties depend on the amount and type of material applied (LOURENÇO et al., 2013), and can vary depending on the soil type and land use and/or management. In the literature, the effects of different management systems and use of pig slurry on soil physical properties have been widely discussed, but few studies have addressed physical properties of

ICentro de Ciências Agroveterinárias (CAV), Universidade do Estado de Santa Catarina (UDESC), Av. Luiz de Camões, 2090, 88520-000,

Lages, SC, Brasil. E-mail: andreiapatricia74@yahoo.com.br. *Corresponding author.

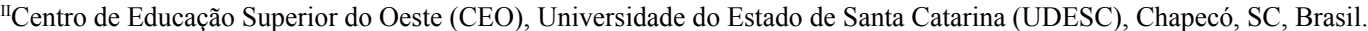


areas under long-term managements with repeated pig slurry (PS) and poultry litter (PL) application.

Evaluating the effect of 15 and 20 years of PS application on the chemical properties of three soils under no-tillage in Santa Catarina, SCHERER et al. (2010) observed no changes in organic carbon in relation to native forest to a depth of $100 \mathrm{~cm}$. MELLEK et al. (2010) tested increasing rates of liquid cattle manure on a Cambisolf or two years, and observed structural improvements in the soil, e.g., a reduction in density and increases in macroporosity and aggregate stability. BARBOSA et al. (2015) evaluated aggregation in a Latosol after PS and PL application and observed an increase in aggregates of $<0.250 \mathrm{~mm}$, between 30 and 60 days after fertilization, in the $0-10 \mathrm{~cm}$ layer. Assessing changes in physical properties of a Latosol, Oliveira et al. (2015) reported no changes after PS application in different soil management systems in the long term, but the land use systems adopted increased bulk density and penetration resistance and reduced the pore volume.

The objective of this study was to evaluate changes in physical properties and organic carbon in a eutroferric Rhodic Kandiudox under different land use and management systems, and successive pig slurry and poultry litter application on livestock farms with long-term use of these organic fertilizers.

\section{MATERIALS AND METHODS}

The study was carried out in Concórdia/ SC, on a eutroferric Rhodic Kandiudoxin a climate classified by Köppen as humid subtropical mesothermal (Cfa), with median annual rainfall, distributed evenly throughout the year (EMBRAPA, 2004).

The land use systems and soil management consisted of areas with different cultivation forms and time of PS and PL application, without mineral fertilization: two maize crops for silage with winter fallow after seven years of manure application (M7), prior to sowing in no-tillage system; two maize crops for silage and winter ryegrass after 20 years of manuring (M20), sown after conventional tillage; pasture after three years of manuring(P3), with oat cultivation/ryegrass in winter and millet/sudan grass in summer with annual chiseling; pasture after 15 years of manuring (P15) with oat cultivation/ryegrass in winter and millet/sudan grass in summer, with annual chiseling; pasture after 20 years of manuring (PP20) with oat/ryegrass/oil seed radish intercrop in the winter and summer fallow, without grazing and one annual cut; yerba mate after 20 years of manuring (YM20) in the rows; native pasture (P0) without manuring and native forest (NF) without human interference. Poultry litter was applied once a year, and pig slurry every three months in all studied areas. The average stocking rate in the areas under dairy cattle grazing was $35-40 \mathrm{ha}^{-1}$ animals.

Pig slurry was applied in liquid form to the soil surface with tractor-drawn equipment, at an annual rate of $50 \mathrm{~m}^{3}$ per hectare (FATMA, 2000) and of $16 \mathrm{~m}^{3}$ per hectare for poultry litter.

Eight soil samples per area were collected from two transects at points spaced 10 meters apart. The layers $0-5,5-10$ and $10-20 \mathrm{~cm}$ were sampled in $20 \times 20 \mathrm{~cm}$ trenches. Soil samples with undisturbed structure were collected in steel rings (diameter $5.0 \mathrm{~cm}$, height $2.5 \mathrm{~cm}$ for the two upper layers and $5 \mathrm{~cm}$ for the lower layer). Samples of soil clods were collected with a spatula from around the sampling points, and stored in plastic bags to evaluate aggregate stability.

Physical analyses were performed according to the methodology described by EMBRAPA (1997). Bulk density (BD) was determined by the volumetric ring method, and particle density (PD) by the volumetric flask method. The volume of biopores (Bio) and micropores (Micro) was determined in a sand box at voltages of 1 and $6 \mathrm{kPa}$, respectively. Total porosity (TP) was calculated by dividing bulk density by particle density. Macroporosity (Macro) was computed by the difference between TP and Micro. Aeration porosity (AP) was calculated as the difference between TP and water content at $1 \mathrm{kPa}$. The plant-available water content (PAW) was estimated by the difference between the water content at a voltage of $3 \mathrm{kPa}$, defined as field capacity and at $1.500 \mathrm{kPa}$, defined as permanent wilting point. Particle size was analyzed by the pipette method and the flocculation degree (FD) was calculated by the amount of clay dispersed in water and total clay (TC). Aggregate stability was determined according to the methodology of Kemper and Chepil (1965) and is represented by the aggregate mean weight diameter (MWD). Soil penetration resistance was evaluated with a fixed penetrometer in the laboratory (PMl) and field equipment (RPf). The PMl was determined in volumetric rings, and moisture equilibrated at a voltage of $6 \mathrm{kPa}$, using a fixed penetrometer, model MA 933/Marconi (cone diameter 3.9mm, penetration angle $45^{\circ}$ and penetration rate of $1 \mathrm{~mm} \mathrm{~s}^{-1}$ ). The PRf was determined in the field with a portable penetrometer, model Falker PLG 1020.

For the analysis of total organic carbon (TOC), total nitrogen (TN) and particulate organic carbon (POC), samples were collected from 3 layers at 10 points (sub-samples) close to the site of 
ring sampling, with a cutting shovel. The soil was blended to form a composite sample. The chemical properties (total organic carbon and total nitrogen) were analyzed according to the methodology described by TEDESCO et al. (1995). Particulate organic carbon (POC) was fractionated as proposed by CAMBARDELLA \& ELLIOT (1992). The carbon to nitrogen $(\mathrm{C}: \mathrm{N})$ ratio was calculated from the relationTOC:TN.

The physical (Macro, Micro, AP, TP, FD, MWD, PMl, PRf, BD, PAW, and TC) and chemical properties (TOC, POC and $\mathrm{C}: \mathrm{N}$ ) were evaluated by principal component analysis (PCA) with land use, management system and fertilizer application time as explanatory variables of modifications, using software CANOCO version 4.0 (TER BRAAK \& SMILAUER, 1998).

\section{RESULTS AND DISCUSSION}

The physical properties and organic carbon contents differed according to the land use and managements under study, especially in a comparison to the areas treated with swine manure and poultry litter with native forest (NF) (Figure 1a, 1b and 1c).

The principal component analysis (PCA) of the $0-5 \mathrm{~cm}$ layer (Figure 1a) differentiated the eight studied areas by the relationship between the first (PC1) and the second principal component 2 (CP2). Of this data variability, $79.3 \%$ was explained by $\mathrm{CP} 1$ and $8.1 \%$ by CP2,i.e., a total of $88.4 \%$ of the variability of the soil physical and chemical properties evaluated. The variables differentiating native forest (NF) from the land use systems were flocculation degree (FD), total porosity, and total organic carbon (TOC). In the NF control treatment, values of TOC, POC, and $\mathrm{C}: \mathrm{N}$ ratio were higher. This shows that land use in crop production systems, regardless of pig slurry and poultry manure application, reduced the TOC content in relation to the natural soil conditions, which can alter the soil quality (RAUBER et al. 2012). COMIN et al. (2013) applied pig slurry for eight years to a Neosol under no-tillage management and reported no increase in TOC content. Conversely, pig slurry applied at rates of $20-80 \mathrm{~m}^{3} \mathrm{ha}^{-1}$ to an Argisol for eight years increased the organic matter content (LOURENZI et al., 2014).

Manure application did not increase the TOC content in the evaluated areas, which may be related to the stimulation of microbial activity by the addition of organic materials with low $\mathrm{C}: \mathrm{N}$, causing intense mineralization of soil organic matter, due to the higher $\mathrm{N}$ availability (GERZABEK et al., 1997).
The FD influenced the distinction between $\mathrm{NF}$ and other land uses and soil managements (Figure 1a). Animal manures added to the soil had predominantly negative charges due to the presence of carboxylic radicals. The increase of these groups is associated with the expansion of the diffuse double layer, which favors the dispersion of soil particles (WUDDIVIRA \& CAMPS-ROACH, 2007). Evaluating clay dispersion and aggregation in a Latosol with application of pig and poultry manure, BARBOSA et al. (2015) reported that this long-term fertilization increased the proportion of microaggregates $(<0.250 \mathrm{~mm})$, thus explaining the increase in clay dispersion. Native forest was strongly correlated with porosity, which may indicate high values of porosity, without depending of microporosity. This indicates that under natural conditions, soil gas flow, water movement and water infiltration capacity are adequate.

Field penetration resistance (PRf) contributed to separate the maize fields (M7 and M20) from the other land use systems and NF (Figure 1a). The relationship between M7 and PRf can be attributed to the export of plant biomass for maize silage and to the fallow period in the winter, leaving the soil bare, favoring consolidation. After 20 years of pig slurry and poultry manure application to maize (M20), this relationship is also caused by the withdrawal of e maize cover and high stock in grates of animals grazed in winter.

Microporosity was higher in maize fields after 7 (M7) and 20 (M20) years of slurry application (Figure1a). This relationship was due to the accommodation of soil particles under conventional tillage and trampling (M20), while in M7 theno-tillage management is deficient since the soil cover in the winter is sparse. In the pasture area without manuring (P0),Micro was higher than in NF, which can be related to the stocking rate and continuous trampling.

The areas of yerba mate (YM20) and pasture (P15) differed from each other in relation to BD, PRl and total clay (TC) (Figure 1a). Bulk density and PMl were related with the P15 area, and the high $\mathrm{BD}$ and $\mathrm{PMl}$ values may be influenced by the constant presence of animals at high soil moisture, facilitating surface compaction. For YM20, this ratio is explained by the traffic of manuring equipment, along the crop rows of yerba mate. These results differ from those of AGNE \& KLEIN (2014), who reported no effect of pig slurry application on bulk density, penetration resistance and porosity in an Oxisol under grazing, after four years of application. 

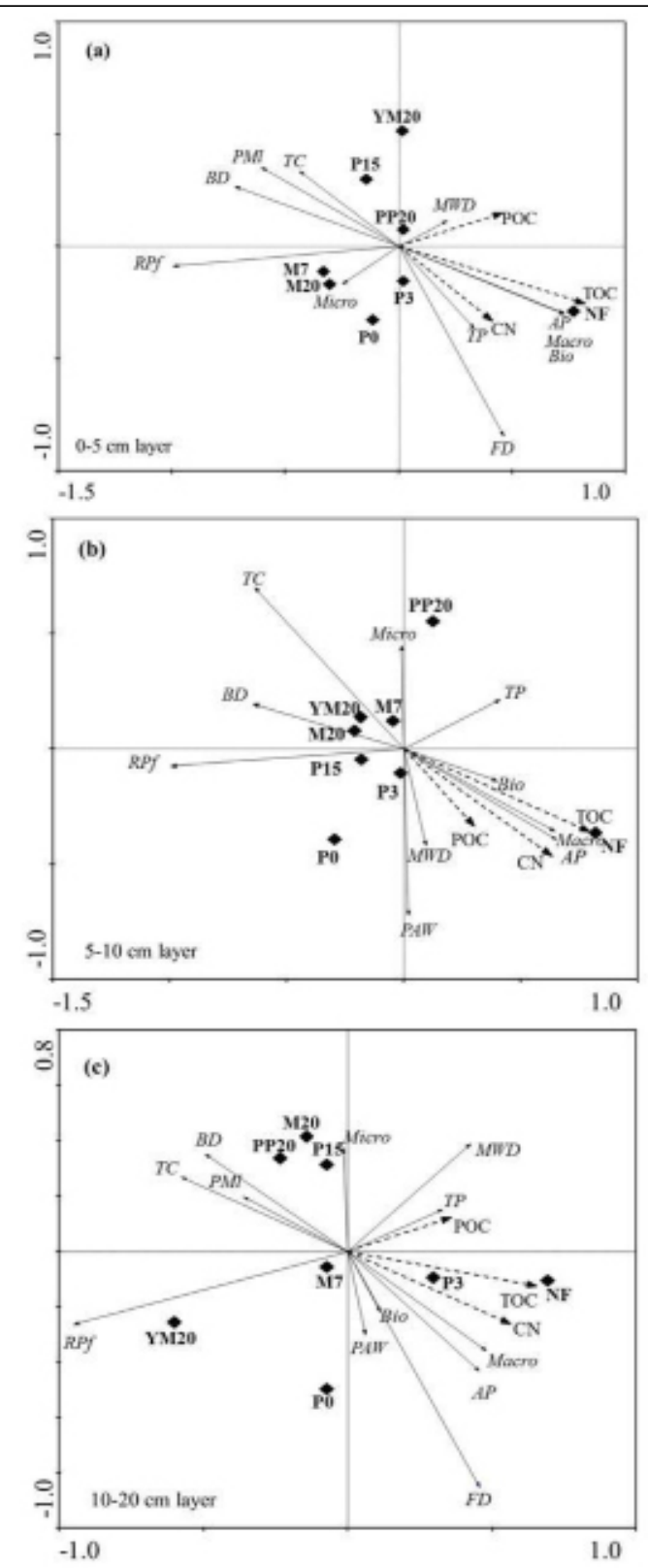

Figure 1 - Diagram of the principal component analysis for the layers 0-5 (a), 5-10 (b) and 10-20cm (c) of a eutroferric Rhodic Kandiudox, under the land uses: native forest (NF), yerba mate after 20 years of manuring (YM20), grassland with 15 years of manuring (P15), grassland with 20 years of manuring (PP20), grassland with 3 years of manuring $(\mathrm{P} 3)$ pasture without manuring $(\mathrm{P} 0)$, maize with 20 years of manuring (M20) and maize after 7 years of manuring (M7) .bio: biopores, Macro: macroporosity, Micro: microporosity, AP: aeration porosity, TP: total porosity, FD: flocculation degree, MWD: aggregate mean weight diameter, PMl and RPf: penetration resistance in the laboratory and field, BD: soil bulk density, PAW: plant-available water, TC: Total clay, TOC: total organic carbon, $(\mathrm{C}: \mathrm{N})$ : carbon nitrogen ratio, POC: particulate organic carbon.

Ciência Rural, v.46, n.5, mai, 2016. 
In the $5-10 \mathrm{~cm}$ layer, the PCA indicated variability among the studied areas (Figure 1b). Of this variability, $78.2 \%$ was explained by $\mathrm{CP} 1$ and $9.6 \%$ by $\mathrm{CP} 2$, totaling $87.8 \%$ of the variability of physical and chemical properties evaluated under different land use and soil management systems. The variables that contributed to the differentiation of treatments with native forest were :TOC, macropores (Macro), aeration porosity (AP), aggregate mean weight diameter (MWD), and plant-available water (PAW).

In this layer,TOC and AP were higher under NF (Figure 1b), indicating that the canopy and absence of soil tillage favor organic carbon storage, increasing its stability in the soil and contributing to the soil structure stability. The MWD diameter associated with NF (Figure 1b) was defined by the favorable environment created in the soil, with permanent cover, high amount of roots and intense biological activity. The PAW in the soil was higher under NF, which can be explained by the positive correlation with organic matter and aggregation, facilitating gas exchange and infiltration, aside from ensuring water retention within aggregates (AGNE \& KLEIN, 2014).

The pasture without waste application (P0) was compared with field penetration resistance (PRf) in the $5-10 \mathrm{~cm}$ layer (Figure 1b), which may be due to animal trampling, as this is a native grassland not treated with recovery measures (liming, fertilizers, introduction of new species). The perennial pasture area (PP20) was related to Micro and TP. This can be explained by the contribution of residues during the long application period without biomass removal and due to effect of grasses root systems (oats and ryegrass) and wild radish. These results differs from those of ARRUDA et al. (2010), who reported no change in micropore volume and total porosity with application of pig slurry in a Latosol.

In the $10-20 \mathrm{~cm}$ layer, $78.2 \%$ of the data variability was explained by $\mathrm{CP} 1$, and $9.6 \%$ byCP2, separating the areas of crop cultivation from those of $\mathrm{NF}$ and pasture (P3). The variables that contributed most to the differentiation were TOC, C:N, Macro, $\mathrm{AP}$, and FD. The relations assigned to $\mathrm{NF}$ as distinctive from the other areas were the same as in the $0-5$ and $5-10 \mathrm{~cm}$. For this layer, the P3 area was very similar to NF (Figure 1c). This may be related to the short-term use of this soil as manured pasture, where carbon content had still not declined and the soil was not broken by tilling.

Field penetration resistance (PRf) was higher in the areas YM20 and P0, evidenced by the high relation between YM20 and P0 with PRf.
The higher PRf can be related to compaction by machine traffic and implements (YM20) and to animal trampling (P0). Areas of maize and permanent pasture after 20 years of manuring (M20, PP20) and grassland after 15 years of manuring (P15) formed a group related by Micro, BD and PRl (Figure 1c).

In the evaluated layers (Figure 1a, 1b and 1c), variables that indicate soil compaction (density and penetration resistance) were higher under land uses with long-term manure fertilization (YM20, $\mathrm{P} 15$ and PP20). Another relevant aspect is that $88.4 \%$ (Figure 1a), 87.8\% (Figure 1b) and 78.2\% (Figure 1c) of the data variability was explained, differentiating the areas for each situation.

\section{CONCLUSION}

The principal component analysis showed that the physical properties and carbon content were influenced by the land use and management systems in the evaluated layers, mainly in a comparison to areas under pig slurry and poultry manure application and native forest.

Soil density and penetration resistance were related to waste application and land use and management. Manuring had no influence on soil organic carbon, except in the $10-20 \mathrm{~cm}$ layer of pasture manured for three years.

\section{ACKNOWLEDGEMENTS}

The Coordenação de Aperfeiçoamento de Pessoal de Nível Superior (CAPES), the granted PhD scholarship the first author.

\section{REFERENCES}

AGNE, S.A.A.; KLEIN, W.A. Matéria orgânica e atributos físicos de um Latossolo Vermelho após aplicações de dejeto de suínos. Revista Brasileira de Engenharia Agrícola e Ambiental, v.18, p.720-726, 2014. Available from: <http://www.agriambi. com.br/index.php?option $=$ com_content $\&$ view $=$ article $\& i d=76$ \&Itemid=11>. Accessed: Mar. 25, 2015. doi: 10.1590/S141543662014000700008

ARRUDA, C.A.O. et al. Aplicação de dejeto suíno e estrutura de um Latossolo Vermelho sob semeadura direta. Ciência e Agrotecnologia, v.34,p.804-809, 2010. Available from: <http:// www.scielo.br/scielo.php? script $=$ sci_arttext\&pid $=\mathrm{S} 1413$ 70542010000400002\&lng=en\&nrm=iso $>$. Accessed: Mar. 25, 2015. doi:10.1590/S1413-70542010000400002.

BANDYOPADHYAY, K.K. et al. Effect of integrated use of farmyard manure and chemical fertilizers on soil physical properties and productivity of soybean. Soil \& Tillage Research, v.110, p.115-125, 2010. Available from: $<$ http://www. sciencedirect.com/science/article/pii/S0167198710001212>. Accessed: Feb. 12, 2015. 
BARBOSA, G.M.C. et al. Aggregation and clay dispersion of an Oxisoltreated with swine and poultry manures. Soil \& Tillage Research, v.146, p.279-285, 2015. Available from: <http://www. sciencedirect.com/science/article/pii/S0167198714002013>. Accessed: Feb. 12, 2015.

CAMBARDELLA, C.A.; ELLIOTT, E.T. Particulate soil organicmatter changes across a grassland cultivation sequence. Soil Science Society of America Journal, v.56, p. 777-783, 1992. Available from: $<$ https://dl.sciencesocieties.org/publications/sssaj/ abstracts/56/3/SS0560030777>. Accessed: Feb. 12, 2015. doi: 10.2136/sssaj1992.03615995005600030017x.

COMIN, J.J. et al. Physical properties and organic carbon content of a TypicHapludult soil fertilised with pig slurry and pig litter in a no-tillage system. Soil Research, v.51,p.459-470, 2013. Available from: <http://www.publish.csiro.au/paper/SR13130. htm $>$. Accessed: Feb. 12, 2015.

EMBRAPA. Centro Nacional de Pesquisa em solos. Manual de métodos de análise de solo. Rio de Janeiro, 1997. 212p.

EMBRAPA. Centro Nacional de Pesquisa em solos. Sistema Brasileiro de Classificação de Solos. Brasília, 2004. 353p.

FATMA (FUNDAÇÃO DE MEIO AMBIENTE DE SANTA CATARINA). Instrução Normativa IN-11. Suinocultura. Portaria Intersetorial n.01/04, de 02.08.2000. Florianópolis, 2000, 11p.

GERZABEK, M.H. et al. The response of soil organic matter to manure amendments in a -long-term experiment at Ultuna, Sweden. European Journal of Soil Science, v. 48, p.273-282, 1997. Available from: <http://www.readcube.com/articles/10.1111 \%2Fj.1365.2389.1997.tb00547.x>. Accessed: Feb. 12, 2015.

KEMPER, W.D.; CHEPIL, W.S.Size distribution of aggregation. In: BLACK, C.A. Methods of soil analysis. Madison: American Society Agronomy, 1965. p.499-510. (Agronomy Monograph, 9).

LOURENZI, C.R. et al. Pig slurry and nutrient accumulation and dry matter and grain yield in various crops. Revista Brasileira de Ciência do Solo, v.38, p.949-958, 2014. Available from: $<$ http://www.scielo.br/scielo.php? script=sci_arttext\&pid=S010006832014000300027\&lng=en\&nrm=iso $>$. Accessed: Mar. 25, 2015. doi: 10.1590/S0100-06832014000300027.
LOURENÇO, K.S. et al. Nutrient uptake and yield of common bean fertilized with poultry litters and mineral nutrients. Revista Brasileira de Ciência do Solo, v.37, p.462-471, 2013. Available from: <http://dx.doi.org/10.1590/S0100-06832013000200017>. Accessed: Jul. 08, 2015.

MELLEK, J.E. et al. Dairy liquid manure and no-tillage: physical and hydraulic properties and carbon stocks in a Cambisol of Southern Brazil. Soil \& Tillage Research, v.110, p. 69-76, 2010.

OLIVEIRA, D.M.S. et al. Qualidade física do solo sob diferentes sistemas de manejo e aplicação de dejeto líquido suíno. Revista Brasileira de Engenharia Agrícola e Ambiental, v. 19, n.3, p. $280-285,2015$. Available from: <http://www. scielo.br/pdf/rbeaa/v19n3/1415-4366-rbeaa-19-03-0280.pdf $>$. Accessed: Jul.07, 2015.

RAUBER, L.P. et al. Physical properties and organic carbon content of a Rhodic Kandiudox fertilized with pig slurry and poultry litter. Revista Brasileira de Ciência do Solo, v.36, p.1323-1332,2012. Available from: <http://www.scielo.br/scielo. php? script $=$ sci arttext\&pid $=$ S0100-06832012000400026\&lng $=$ en\&nrm=iso $>$. Accessed: Mar. 25, 2015. doi:10.1590/S010006832012000400026

SCHERER, E.E. et al. Atributos químicos do solo influenciados por sucessivas aplicações de dejetos suínos em áreas agrícolas de Santa Catarina. Revista Brasileira de Ciência do Solo, v.34, p.1375-1383, 2010. Available from: <http://www.scielo.br/scielo. php?script=sci_arttext\&pid=S0100-06832010000400034\&lng $=$ en $\& n r m=$ iso $>$. Accessed: Mar. 25, 2015. doi:10.1590/S010006832010000400034 .

TEDESCO, M.J.et al. Análises de solo, plantas e outros materiais. 2.ed. Porto Alegre: Universidade Federal do Rio Grande do Sul, 1995.174p.

TER BRAAK, C.J.F.; SMILAUER, P. CANOCO reference manual and user's guide to Canoco for Windows: software for canonical community ordination. New York: Microcomputer Power, 1998. Version 4.

WUDDIVIRA, M.N.; CAMPS-ROACH, G. Effects of organic matter and calcium on soil structural stability. European Journal of Soil Science, v.58, p.722-727, 2007. 